\title{
PERIODONTAL CONDITION IN RELATION TO THE ADHERENCE TO NUTRIENT RECOMMENDATIONS IN DAILY SMOKERS
}

\author{
Jauhiainen $L^{1,2}$, Suominen AL ${ }^{1,3,4,5}$, Männistö $S^{6}$, Knuuttila $M^{7,8}$, Ylöstalo $P^{1,3,7,8}$ \\ ${ }^{1}$ Institute of Dentistry, University of Eastern Finland, Kuopio, Finland \\ ${ }^{2}$ City of Kuopio, Health Centre, Oral Health Care Services \\ ${ }^{3}$ Department of Oral and Maxillofacial Surgery, Kuopio University Hospital, Kuopio, Finland \\ ${ }^{4}$ Living Environment and Health Unit, National Institute for Health and Welfare, Kuopio, Finland \\ ${ }^{5}$ Health Monitoring Unit, National Institute for Health and Welfare, Helsinki, Finland \\ ${ }^{6}$ Department of Health and Social Care Systems, National Institute for Health and Welfare, \\ Helsinki, Finland \\ ${ }^{7}$ Department of Oral and Maxillofacial Surgery, Oulu University Hospital, Oulu, Finland \\ ${ }^{8}$ Unit of Oral Health Sciences, Medical Research Center Oulu (MRC Oulu), Oulu University \\ Hospital and University of Oulu, Oulu, Finland
}

Corresponding author: Leena Jauhiainen

Address: University of Eastern Finland, Institute of Dentistry, Kuopio Campus, PL 1627, 70211

Kuopio

Tel: +358403552442

Fax: +358403552442

E-mail: leena.jauhiainen@uef.fi

Running title: Diet and periodontal health in smokers

Keywords: Periodontal diseases, periodontitis, gingival diseases, diet, nutrition. 


\section{Conflicts of interest and source of funding}

No conflicts of interest to declare.

The present study is part of the Health 2000 Survey, organised by the National Institute for Health and Welfare (THL), the former Public Health Institute (KTL) of Finland (http://www.terveys2000.fi/indexe.html), and partly supported by the Finnish Dental Society Apollonia and the Finnish Dental Association. Personal grants to Leena Jauhiainen from the Finnish Dental Society Apollonia and the Olvi-foundation are acknowledged. 


\begin{abstract}
Aim: To examine whether a healthy diet based on nutrient recommendations is associated with periodontal condition in smokers.

Material and methods: Daily smokers from the cross-sectional Health 2000 Survey in Finland, analyzed in two age groups (30-49 and 50-79 years, $n=704$ and 267) and according to the level of oral hygiene. Periodontal condition was measured as the number of sextants with gingival bleeding and teeth with $\geq 4 \mathrm{~mm}$ deepened periodontal pockets. Information on nutrition was collected by a validated food frequency questionnaire and measured using the Baltic Sea Diet Score (BSDS) and the Recommended Finnish Diet Score (RFDS).
\end{abstract}

Results: In the total study population, no association between the scores and periodontal condition was observed. Among 30-49-year-old participants with good oral hygiene, diet scores associated inversely with the number of teeth with deepened periodontal pockets ( $\mathrm{p}=0.078$ (BSDS) and $\mathrm{p}=0.027(\operatorname{RFDS}))$.

Conclusions: In a representative sample of Finnish adults who smoke, a healthy diet was not associated with periodontal condition. Among a younger age group with good oral hygiene, a healthy diet associated with better periodontal condition. Age and oral hygiene appeared to modify the association between diet and periodontal condition. 


\section{Clinical relevance}

Scientific rationale for the study: Additional ways to improve periodontal health among smokers are required. To date, there is a lack of evidence whether periodontal health among smokers could be improved by following a healthy diet.

Principal finding: A healthy diet was found to be inversely associated with the number of teeth with deepened periodontal pockets among 30-49-year-old smokers in the absence of other commonly accepted risk factors of periodontitis.

Practical implications: It is likely that young smokers without other risk factors for periodontitis benefit most from dietary counselling. 


\section{Introduction}

Reactive oxygen species (ROS) participate in killing bacteria together with granular proteases and extracellular traps (reviewed by Roos et al. 2003, Cooper et al. 2013). It has been observed that if present in lower concentrations, ROS activate redox-sensitive gene transcription factors, such as nuclear factor- $\mathrm{\kappa B}$ or activating protein-1, which in turn induces the production of pro-inflammatory cytokines. In larger amounts, ROS are able to break down macromolecules such as proteins and lipids. In addition, the oxidation of the above-mentioned products may increase the oxidative load in the periodontium due to prolonged transit times of neutrophils through periodontal tissues (reviewed by Chapple \& Matthews 2007).

Antioxidants are agents that resist oxidative stress. They can be either endogenously generated, such as glutathione peroxidase and superoxide dismutase for example, or food derived, such as vitamins A, C and E and flavonoids (reviewed by Chapple \& Matthews 2007). Compared with nonsmokers, smokers have been reported to have lower antioxidant storages (Faruque et al. 1995, Agnihotri et al. 2009, Schleicher et al. 2009), which can be partly explained by the increased use of antioxidants, possibly related to increased release of ROS among smokers (Ryder 1998, Matthews 2012). This suggests that smokers are less protected against oxidative stress than non-smokers.

In addition to being antioxidative, food can also be a source of oxidative stress, as eating caloriedense and nutritionally depleted food increases oxidative stress in the body. It has been observed that the excess energy causes the citric acid cycle to become overloaded, leading to the release of ROS and pro-inflammatory cytokines, if the diet includes high amounts of refined sugars and saturated fats (reviewed by Muñoz \& Costa 2013). Earlier studies have reported that added sugars (Lula et al. 2014), low fibre intake (Nielsen et al 2016) and low antioxidant intake (Ismail et al. 1983, Nishida et al. 2000, Iwasaki et al. 2012), and high intake of saturated fats (Iwasaki et al. 2011) are associated with poorer periodontal health.

A healthy diet, measured using the Baltic Sea Diet Score (BSDS), has earlier been found to be associated with low C-reactive protein concentration (CRP) (Kanerva et al. 2014a). In our previous study, we reported that a healthy diet of this kind, measured using BSDS and the Recommended Finnish Diet Score (RFDS), associated inversely with gingival bleeding, especially among those with poor oral hygiene (Jauhiainen et al. 2016). Based on earlier findings and the current view on the pathogenesis of periodontitis, we hypothesized that smokers would benefit from a healthy diet 
due to their increased exposure to oxidative stress. Subsequently, the aim of this paper was to examine whether a healthy diet based on nutrient recommendations is associated with periodontal condition in daily smokers.

\section{Material and methods}

This study was based on the data from the nationally representative cross-sectional Health 2000 Survey conducted in 2000-2001 by the National Institute for Health and Welfare (THL) (former National Public Health Institute (KTL) of Finland) (Aromaa \& Koskinen 2004). The main sample of the Health 2000 Survey consisted of individuals aged 30 years and over ( $n=8028)$, of which 6986 subjects took part in a home interview, 6354 in a clinical health examination, 6335 in an oral health examination. Those attending the clinical health examination received a food frequency questionnaire (FFQ), which they filled in at home and sent by mail to the National Institute for Health and Welfare. Of the returned questionnaires, 5998 were filled in acceptably.

The number of participants aged 30 to 79 years who attended the oral health examination was 6043 . After excluding people with diabetes $(n=620)$, rheumatoid arthritis $(n=160)$, and those who had missing information on nutrition $(\mathrm{n}=400)$ and periodontal parameters $(\mathrm{n}=545)$, and including only daily smokers who smoked cigarettes or burns, the final study population consisted of 971 people. These individuals were categorized into two age groups, the younger age group consisting of people between 30-49 years $(n=704)$ and the older one of people between 50-79 years $(n=267)$.

\section{Clinical oral health examination}

Periodontal pocket depths were measured on every tooth except wisdom teeth and tooth remnants using $20 \mathrm{~g}$ force. Periodontal pockets were measured on four surfaces of every tooth: distobuccal, buccal, mesiolingual and lingual surfaces. Measurements were registered as follows: "no periodontal pocket", "a periodontal pocket between 4-5 mm deep" and "a periodontal pocket $6 \mathrm{~mm}$ deep or deeper". Only the deepest pocket of each tooth was recorded. For the analyses, the latter two categories were combined. Gingival bleeding was based on bleeding on probing that was observed immediately after probing. It was recorded on a maximum of three sextants per upper jaw 
and three sextants per lower jaw (Vehkalahti et al. 2008). The recording was done if there were at least two teeth per sextant.

A reference dentist took parallel measurements of pocket depths and gingival bleeding on several visits. The percentual agreement for pocket depth measurements between the reference dentist and the field-dentists was 77\% (К-value 0.41). The repeatability among the field-dentists showed a кvalue of 0.83. (Vehkalahti et al. 2004). The percentual agreement for measurements of gingival bleeding between the reference dentist and the field-dentists was $66 \%$ ( $\mathrm{K}$-value 0.36 ). The repeatability among the field-dentist showed a к-value of 0.66 (Vehkalahti et al 2004).

\section{Information of dietary variables}

Diet was measured using a validated Food Frequency Questionnaire (FFQ) (Männistö et al. 1996, Paalanen et al. 2006). The FFQ consisted of 128 food items, which takes into account the whole diet over the previous 12 months. Nine frequency categories of the use of foods ranged from never or rarely to six or more times a day. The portion sizes were fixed and specified using natural units (e.g. cups of coffee). Food consumption was converted into grams per day so that the frequency of the food item was multiplied by a fixed portion size. Daily food consumption and nutrient intakes were calculated using the national food composition database, Fineli ${ }^{\circledR}$ (Reinivuo et al. 2010).

In order to assess the quality of the diet, two complementary scores were used: The Baltic Sea Diet Score (BSDS) (Kanerva et al. 2014b) and the Recommend Finnish Diet Score (RFDS) (Kanerva et al. 2013), which are both based on nutrient recommendations. BSDS includes only food items that are produced locally and traditionally eaten in the Nordic countries, whereas RFDS is more comprehensive and includes also non-local components, such as oranges for example.

In the BSDS, there were nine score components, of which six were food groups and three represented nutrients. Six of these variables were categorized as positive and three as negative. Positive variables were fruits and berries (apples, pears and berries); vegetables (leafy vegetables, cucumber, tomatoes, peas, cabbages and roots, excluding potato); cereals (rye, oats and barley); low-fat milk (low-fat and fat-free milk); fish (salmon and freshwater fish); and fat ratio (the ratio of polyunsaturated fatty acids (PUFA) to saturated fat (SFA) and trans-fatty acids). Negative variables were red meat (beef, pork, processed meat products and sausage); total fat intake as a percentage of 
the total energy intake (E\%); and alcohol (ethanol intake). The score was calculated according to quartiles of consumption for each score component. For the positive score components, the lowest quartile was given 0 points, the second one 1 point, the third one 2 points and the highest quartile of intake 3 points. For the negative score components, points were given in reverse order, with the exception of alcohol, which was given 0-1 point (one point was given if the ethanol intake was < $20 \mathrm{~g}$ for men and $<10 \mathrm{~g}$ for women, otherwise zero points were given). The points given for each component were summed up to obtain the overall score. The resulting BSDS ranged from 0 to 25 . The higher the score, the healthier the diet. In the analysis, BSDS was used as a continuous variable and categorized into tertiles. In both age groups, the category boundaries for tertiles were: scores $2-$ 11 for the lowest tertile, scores 12-14 for the middle tertile and scores 15-24 for the highest tertile.

RFDS included eight components, of which four were food groups and four represented nutrients. Five of these components were categorized as positive and three as negative. The five positive components were fruits (apples, citruses and other fruits and berries); vegetables (fruit vegetables, leafy vegetables, roots, cabbages, legumes, mushrooms, excluding potato); the ratio of white meat (poultry, fish and fish products) to red and processed meat (beef, pork, lamb, sausage, meat products, game and offal); rye, which was used to represent dietary fibre and is the most common source of fibre in Finland; and the ratio of PUFA to SFA and trans-fatty acids. The three negative components of the score were salt (g/day), sucrose (E\%) and alcohol (E\%). The score was calculated according to quartiles of consumption of each score component. For the positive score components, the lowest quartile was given 0 points, the second one 1 point, the third one 2 points and the highest quartile of intake 3 points. For the negative score components, points were given in reverse order. The points given for each component were summed up to obtain the overall score. The resulting RFDS ranged from 0 to 24 . The higher the score, the healthier the diet. In the analysis, RFDS was used as a continuous variable and categorized into tertiles. In the younger age group, the category boundaries for tertiles were: scores $0-7$ for the lowest tertile, scores 8-10 for the middle tertile and scores 11-18 for the highest tertile. In the older age group the scores were 17, 8-10 and 11-17, respectively.

To avoid the confounding effect of total energy intake related to physical activity, differences in body size and energy efficiency, all the nutrition intake variables except alcohol E\%, were corrected before applying regression models using the Willett residual method, which takes into account the 
amount of total energy in relation to the intake of nutrients between participants (Willett \& Stampfer 1986).

\section{Information on smoking}

Information on smoking was asked as part of the home interview. Participants were considered to be daily smokers if they reported having smoked daily for at least one year and the most recent smoking occasion was on the day of the interview or the day before. In this study, only those who smoked cigarettes or burns daily were included. The number of cigarettes smoked was used as a continuous variable in the adjusted models.

\section{Information on potential confounding variables}

The level of education was asked as a part of the home interview. It was assessed using information on formal schooling and vocational training. Education was categorized into three categories: basic, intermediate and higher education. Those with no formal vocational training or senior secondary education were classified as having basic education. Those who had completed vocational training or passed the matriculation examination were considered as having intermediate education. Those with higher education had degrees or diplomas from higher vocational institutions, polytechnics and universities.

Information on toothbrushing frequency was asked as part of the health interview and selfadministered questionnaire and it was categorized into the following categories: more often than twice a day, twice a day, once a day, less than once a day or never. Dental attendance patterns were asked in the interview preceding the health examination or during the home health examination and it was categorized into the following categories: visiting dentist regularly for a check-up vs. visiting dentist only when experiencing toothache or other symptoms or never.

Information on physical activity was asked as part of a self-administered questionnaire by using the Gotherburg scale and the International Physical Activity Questionnaire (IPAQ) scale measuring physical activity during leisure time, household work, walking and sitting (Aromaa 2008). 
Information on the use of medication was asked as part of the interview. Participants were asked to indicate the names of the medicines they had used during the past seven days, and the responses were checked by the interviewer from packages or prescriptions. Medicines were further classified in accordance with the Pharmaca Fennica prescription medicine compendium (Nieminen 2008).

Information on the use of supplements was obtained from the FFQ and was used as a dichotomous variable (regular use $v s$. no use). CRP was measured during the clinical health examination as part of the laboratory testing and was used as a continuous variable.

The body mass index (BMI) is a measure of weight (kilograms) in relation to the square of height (metres) $\left(\mathrm{kg} / \mathrm{m}^{2}\right)$. Trained persons measured the weight and height of the subjects during the clinical health examination. If these data were not obtained in the clinical health examination, they were collected by means of questionnaires and interviews.

The level of oral hygiene was based on the presence of dental plaque. The presence of dental plaque was observed in the examination of clinical oral health modified from Silness and Löe (Silness \& Löe 1964). Plaque was measured on one surface of three teeth: the buccal surface of the most posterior tooth on the upper right side; the lingual surface of the most posterior tooth on the lower left side and the buccal surface of tooth 33 . The presence of plaque was registered as no visible plaque, visible plaque in gingival margins and visible plaque elsewhere. The highest value of the indicator teeth was used to describe the level of oral hygiene. In the stratified analyses, the ones who had no visible plaque on the teeth were categorized as having good oral hygiene, and those with visible plaque in gingival margins or visible plaque elsewhere on the teeth as having poor oral hygiene.

\section{Statistical methods}

Two-stage cluster sampling and weighting for non-response were used to obtain representative data for the target population of the survey. Poisson regression was used to estimate prevalence rate ratios (PRR), 95\% confidence intervals and p-values.

The models were adjusted for age, gender, number of cigarettes smoked, level of education, toothbrushing frequency, dental attendance pattern, use of supplements, logarithmically 
transformed CRP, BMI, oral hygiene, the use of non-steroidal anti-inflammatory drugs (NSAID) and physical exercise. The number of teeth and the number of measured sextants were used as offset variables.

To take into account the two-stage cluster sampling design, the data analyses were performed using SAS Callable SUDAAN Research Triangle Institute, Raleigh NC, USA (Release 11.0.1.) software.

\section{Results}

\section{Characteristics of the study population}

The study population consisted of 30-79-year-old participants of which 53\% were males and $47 \%$ females. In the younger age group (30-49 years) $52 \%$ were males and $48 \%$ females while the corresponding figures for the older age group (50-79 years) were 57\% and 43\%. The two age groups differed in the level of education, the level of oral hygiene and also in the number of teeth with deepened periodontal pockets in such a way that the older age group had a higher proportion of subjects with only basic education, poor oral hygiene and a higher number of teeth with deepened periodontal pockets than in the younger age group (Table 1).

Table 2 describes the background characteristics of the two age groups in relation to the tertiles for the BSDS and RFDS. There was a difference in the proportion of men and women in the highest and lowest tertiles of BSDS and RFDS: women had higher scores than men, which indicates that women had on average a healthier diet than men. Furthermore, the oral hygiene of those with high scores was better than that of those with low scores. In the older age group, CRP was inversely associated with the tertiles for BSDS and RFDS.

\section{$B S D S$ and RFDS in relation to periodontal outcomes}

Table 3 shows the mean scores of BSDS and RFDS in relation to gingival bleeding and periodontal pocketing. The number of teeth with deepened periodontal pockets was inversely associated with the mean scores of BSDS and RFDS, whereas the association between the number of sextants with gingival bleeding and BSDS and RFDS was inconsistent. 
Tables 4 and 5 show the associations between tertiles of BSDS and RFDS and the number of sextants with gingival bleeding and teeth with deepened periodontal pockets in unadjusted and adjusted models. In the adjusted models, there were practically no associations between scores and the number of sextants with gingival bleeding or teeth with deepened periodontal pockets in either age group.

\section{Results of stratified analysis}

In the younger age group, the number of teeth with deepened periodontal pockets was inversely associated with RFDS $(\mathrm{p}=0.027)$ and BSDS $(\mathrm{p}=0.078)$ among those with good oral hygiene. The corresponding $\mathrm{p}$-values in the older age group with good oral hygiene were $\mathrm{p}=0.124$ (RFDS) and $\mathrm{p}=0.783(\mathrm{BSDS})($ Tables 4 and 5).

\section{Discussion}

\section{Current and earlier findings}

In this paper we aimed to examine whether a healthy diet, based on nutrient recommendations, is associated with periodontal condition among those who smoked daily. The aim was based on the hypothesis that smokers would benefit from a healthy diet, possibly due to their increased exposure to oxidative stress. Contrary to the hypothesis, we did not observe any consistent association between diet and periodontal condition in this representative sample of 30-79-year-old Finnish smoking adults. However, we observed a weak inverse association between the number of teeth with deepened periodontal pockets and a healthy diet among 30-49-year-old smokers with good oral hygiene.

Currently, there are a few studies on whole diet and periodontal diseases, but there is only one study in which smokers were analyzed separately. In that study, the intake of fruits and vegetables, $\beta$ carotene, vitamin $\mathrm{C}, \alpha$-tocopherole, vitamin D, $\alpha$-linoleic acid, eicosapentaenoic acid (EPA) and docosahecsaenoic acid (DHA) was reported to associate with periodontal healing among nonsmokers, but not among smokers (Dodington et al. 2015). In line with what Dodington reported in 
the non-experimental study among non-smokers, also interventional studies conducted among nonsmoking populations suggest that a healthy diet improves the condition of periodontium. For example, it has been observed in two interventional studies including people with metabolic syndrome or being at a risk to develop it, that having a high-fibre and low-fat diet or wholesome nutrition improved both the clinical signs in the periodontium and also cytokine levels in gingival crevicular fluid (Jenzsch et al. 2009) and plasma (Kondo et al. 2014). Decreased clinical signs of inflammation were also observed in an interventional study by Woelber (Woelber et al. 2017) (a diet low in carbohydrates and omega- 6 polyunsaturated fatty acids and high in omega- 3 fatty acids, vitamin C and D, antioxidants and fibre), and by Baumgartner (Baumgartner et al. 2009) (a Stone Age diet) in the absence of oral hygiene. The earlier results of the Health 2000 data also support the view that a healthy diet is associated with less gingival bleeding in a non-smoking population (Jauhiainen et. al. 2016).

\section{Possible explanations for the findings}

In periodontal destruction among smokers, the balance between the protective and destructive functions of neutrophils is distorted towards destructive functions; chemotaxis and phagocytosis are impaired partly due to the impaired ability of neutrophils to produce ROS and reduced levels of immunoglobulins A and G (Ryder 1998, reviewed by Ryder 2007, Matthews 2011, 2012). In addition to the microbiological effects, smoking also causes constriction of the blood vessels in the periodontium, which masks the clinical signs of inflammation in the periodontium (Kumar \& Faizuddin 2011). This vasoconstriction effect may partly explain why diet did not associate with gingival bleeding among smokers.

The lack of a consistent association between diet and periodontal condition in smokers may also be explained by earlier findings suggesting that smokers should eat twice as much vitamin $\mathrm{C}$ per day than non-smokers to reach the same concentration in the serum (Schectman et al. 1991). This problem concerns solely vitamin $\mathrm{C}$, as in another study, other dietary antioxidants reached the same concentration in the serum of smokers and non-smokers with similar dietary intake and the concentration of vitamin C was also normalized after supplementation (Lykkesfeldt et al. 2000).

If the finding of the stratified analyses - an inverse association between the number of teeth with deepened periodontal pockets and a healthy diet among daily smokers with good oral hygiene - is 
true, the fact that it can be seen only in the absence of the most important risk (poor oral hygiene) and only in younger people means that the association between diet with periodontal condition is most likely weak - at least when compared with other risk factors or disease determinants. Selfevidently, the central question is whether the prevalence rates ratios, which in this study were below one among those with better adherence to a healthy diet, truly reflect their reduced risk of periodontal disease, or whether this is due to confounding related to attitudinal factors or unmeasured aspects of health behaviour for example.

\section{Strengths and limitations}

One of the weaknesses of this study is that the number of daily smokers in the categories of explanatory variables, especially in the stratified analysis, was low, which increased the possibility of a chance finding and self-evidently led to larger confidence intervals and higher p-values. This problem was evident particularly in the older age group.

Another weakness of this study is the measurement of oral hygiene. Due to the limited time for oral examination, it was not possible to obtain tooth or surface level data for plaque and therefore the data were collected on three indicator teeth using a modified version of Silness and Löe. Despite the rough level of the measurement, this variable has been found to be strongly associated with the number of teeth with deepened periodontal pockets in the Health 2000 data (Saxlin et al. 2008).

To overcome the effect of competing risks, we excluded diabetic patients and those with rheumatoid arthritis from the study and made stratified analyses according to oral hygiene level. To minimize the possibility that the observed benefits are age-related due to different risk factor profiles (diet, biology, the presence of competing risk factors, non-oral illnesses and the participants' medications), we divided the study population into two age groups (30-49 and 50-79). The decision to use these age groupings was based on the fact that in 50 years there was a fairly clear change in the number of teeth and the number of teeth with $(\geq 4 \mathrm{~mm})$ deepened periodontal pockets.

\section{Concluding remarks}


In this study, we observed that healthy diet was associated with a low number of teeth with deepened periodontal pockets among 30-49-year-old individuals who smoked daily but who had no other commonly accepted risk factors of periodontitis, i.e. diabetes and poor oral hygiene. From the point of view of treatment, we can interpret this observation in such a way that this group benefits most from dietary counselling.

The fact that we could not observe an association of diet with gingival bleeding or periodontal pocketing in the total smoking population suggests that age, or closely age-related factors, and the level of oral hygiene modified the association between diet and periodontal condition. Based on a fairly weak association between diet and periodontal condition, and the fact that the association was observable only in the absence of major risk factors, we conclude that the possible effect of a healthy diet on the periodontal health of a smoking population with a reasonably healthy diet is most likely small, although not non-existent.

\section{References}

Agnihotri, R., Pandurang, P., Kamath, S.U., Goyal, R., Ballal, S., Shanbhogue, A.Y., Kamath, U., Bhat, G.S. \& Bhat, K.M. (2009) Association of cigarette smoking with superoxide dismutase enzyme levels in subjects with chronic periodontitis. J Periodontol. 80, 657-62

Aromaa, A. (2008) Basic questionnaire. In: Heistaro, S. (ed.) Methodology Report Health 2000 Survey, p. 51. Helsinki: Publications of the National Public Health Institute B26/2008.

Aromaa, A. \& Koskinen, S. (2004) Population and methods. In: Aromaa, A. \& Koskinen, S. (ed.) Health and Functional Capacity in Finland - Baseline Results of the Health 2000 Health Examination Survey, pp. 11-14. Helsinki: Publications of the National Public Health Institute B12/2004.

Baumgartner, S., Imfeld, T., Schicht, O., Rath, C., Persson, R.E. \& Persson, G.R. (2009) The impact of the stone age diet on gingival conditions in the absence of oral hygiene. $J$ Periodontol. 80, 759-768

Chapple, I.L.C. \& Matthews, J.B. (2007) The role of reactive oxygen antioxidant species in 
periodontal tissue destruction. Periodontol 2000 43, 160-232.

Cooper, P.R., Palmer, L.J. \& Chapple, I.L.C. (2013) Neutrophil extracellular traps as a new paradigm in innate immunity: friend or foe? Periodontol 2000 63, 165-197.

Dodington, D.W., Fritz, P.C., Sullivan, P.J. \& Ward W.E. (2015) Higher Intakes of Fruits and Vegetables, $\beta$-Carotene, Vitamin C, $\alpha$-Tocopherol, EPA, and DHA Are Positively Associated with Periodontal Healing after Nonsurgical Periodontal Therapy in Nonsmokers but Not in Smokers. $J$ Nutr. 145, 2512-2519.

Faruque, M,O., Khan, M.R., Rahman, M.M. \& Ahmed, F. (1995) Relationship between smoking and antioxidant nutrient status. Br J Nutr. 73, 625-632.

Iwasaki, M., Manz, M.C., Moynihan, P., Yoshihara, A., Muramatsu, K., Watanabe, R. \& Miyazaki, H. (2011) Relationship between saturated fatty acids and periodontal disease. J Dent Res. 90, 861867.

Iwasaki, M., Moynihan, P., Manz, M.C., Taylor, G.W., Yoshihara, A., Muramatsu, K., Watanabe, R. \& Miyazaki, H. (2012) Dietary antioxidants and periodontal disease in community-based older Japanese: a 2-year follow-up. Public Health Nutr. 16, 330-338.

Ismail, A.I., Burt, B.A. \& Eklund, S.A. (1983) Relation between ascorbic acid intake and periodontal disease in the United States. J Am Dent Assoc. 107, 927-931.

Jauhiainen, L., Suominen, A.L., Männistö, S., Kanerva, N., Knuuttila, M. \& Ylöstalo, P. (2016) Periodontal Pocketing and Gingival Bleeding in Relation to Nordic Diet - results from a populationbased survey. J Clin Periodontol. 43, 1013-1023.

Jenzsch, A., Eick, S., Rassoul, F., Purschwitz, R. \& Jentsch H. (2009) Nutritional intervention in patients with periodontal disease: clinical, immunological and microbiological variables during 12 months. Br J Nutr. 101, 879-885. 
Kanerva, N., Kaartinen, N.E., Ovaskainen M.L., Konttinen, H., Kontto, J. \& Männistö S. (2013) A diet following Finnish nutritional recommendations does not contribute to the current epidemic of obesity. Public Health Nutr. 16, 786-794.

Kanerva, N., Loo, B.M., Eriksson, J.G., Leiviskä, J., Kaartinen, N.E., Jula, A. \& Männistö S. (2014a) Associations of the Baltic Sea diet with obesity-related markers of inflammation. Ann Med. 46, 90-96.

Kanerva, N., Kaartinen, N.E., Schwab, U., Lahti-Koski, M. \& Männistö S. (2014b) The Baltic Sea Diet Score: a tool for assessing healthy eating in Nordic countries. Public Health Nutr. 17, 16971705.

Kondo, K., Ishikado, A., Morino, K., Nishio, Y., Ugi, S., Kajiwara, S., Kurihara, M., Iwakawa, H., Nakao, K., Uesaki, S., Shigeta, Y., Imanaka, H., Yoshizaki, T., Sekine, O., Makino, T., Maegawa, H., King, G.L., Kashiwagi, A. (2014) A high-fiber, low-fat diet improves periodontal disease markers in high-risk subjects: a pilot study. Nutr Res. 34, 491-498.

Kumar, V. \& Faizuddin, M. (2011) Effect of smoking on gingival microvasculature: a histological study. J Indian Soc Periodontol. 15, 344-348.

Lula, E.C., Ribeiro, C.C., Hugo, F.N., Alves, C.M. \& Silva, A.A. (2014) Added sugars and periodontal disease in young adults: an analysis of NHANES III data. Am J Clin Nutr. 100, 1182 1187.

Lykkesfeldt, J., Christen, S., Wallock, L.M., Chang, H.H., Jacob, R.A. \& Ames, B.N. (2000) Ascorbate is depleted by smoking and repleted by moderate supplementation: a study in male smokers and nonsmokers with matched dietary antioxidant intakes. Am J Clin Nutr. 71, 530-536.

Matthews, J.B., Chen, F.M., Milward, M.R., Wright, H.J., Carter, K., McDonagh, A. \& Chapple, I.L. (2011) Effect of nicotine, cotinine and cigarette smoke extract on the neutrophil respiratory burst. J Clin Periodontol. 38, 208-218. 
Matthews, J.B., Chen, F.M., Milward, M.R., Ling, M.R. \& Chapple, I.L. (2012) Neutrophil superoxide production in the presence of cigarette smoke extract, nicotine and cotinine. J Clin Periodontol. 39, 626-634.

Muñoz, A. \& Costa, M. (2013) Nutritionally mediated oxidative stress and inflammation. Oxid Med Cell Longev. 2013, 610950.

Männistö, S., Virtanen, M., Mikkonen, T. \& Pietinen, P. (1996) Reproducibility and validity of a food frequency questionnaire in a case-control study on breast cancer. J Clin Epidemiol 49, 401409

Nielsen, S.J., Trak-Fellermeier, M.A., Joshipura, K. \& Dye, B.A. (2016) Dietary Fiber Intake Is Inversely Associated with Periodontal Disease among US Adults. J Nutr. 146, 2530-2536.

Nieminen, T. (2008) Home-visit interview. In: Heistaro, S. (ed.) Methodology Report Health 2000 Survey, p. 42. Helsinki: Publications of the National Public Health Institute B26/2008.

Nishida, M., Grossi, S.G., Dunford, R.G., Ho, A.W., Trevisan, M. \& Genco R.J. (2000) Dietary vitamin C and the risk for periodontal disease. J Periodontol 71, 1215-1223.

Paalanen, L., Männistö, S., Virtanen, MJ., Knekt, P., Räsänen, L., Montonen, J. \& Pietinen P. (2006) Validity of a food frequency questionnaire varied by age and body mass index. Journal of Clinical Epidemiology 59, 994-1001.

Reinivuo, H., Hirvonen, T., Ovaskainen, M.L., Korhonen, T. \& Valsta, L.M. (2010) Dietary survey methodology of FINDIET 2007 with a risk assessment perspective. Public Health Nutr. 13, 915919.

Roos, D., Van Bruggen, R. \& Meischl, C. (2003) Oxidative killing of microbes by neutrophils. Microbes Infect 5, 1307-1315.

Ryder, M.I., Fujitaki, R., Johnson, G. \& Hyun, W. (1998) Alterations of neutrophil oxidative burst by in vitro smoke exposure: implications for oral and systemic diseases. Ann Periodontol. 3, 76-87. 
Ryder, M.I. (2007) The influence of smoking on host responses in periodontal infections.

Periodontol 2000 43, 267-277.

Saxlin, T., Suominen-Taipale, L., Kattainen, A., Marniemi, J., Knuuttila, M. \& Ylöstalo, P. (2008)

Association between serum lipid levels and periodontal infection. J Clin Periodontol 35, 10401047.

Schectman, G., Byrd, J.C. \& Hoffmann, R. (1991) Ascorbic acid requirements for smokers: analysis of a population survey. Am J Clin Nutr. 53, 1466-1470.

Schleicher, R.L., Carroll, M.D., Ford, E.S. \& Lacher, D.A. (2009) Serum vitamin C and the prevalence of vitamin C deficiency in the United States: 2003-2004 National Health and Nutrition Examination Survey (NHANES). Am J Clin Nutr. 90, 1252-1263.

Silness, J. \& Löe, H. (1964) Periodontal disease in pregnancy. II. Correlation between oral hygiene and periodontal condition. Acta Odontologica Scandinavica 22, 121-135.

Vehkalahti, M., Knuuttila, M. \& Hausen, H. (2004) Kliinisten mittausten laadun varmistaminen (Quality assurance of clinical examinations). In: Suominen-Taipale, L., Nordblad, A., Vehkalahti, M. \& Aromaa, A. (eds) Suomalaisten aikuisten suunterveys, Terveys 2000 -tutkimus (Oral Health of Finnish Adults, Health 2000 Health Examination Survey), pp. 24-32. Helsinki: Publications of the National Public Health Institute B16/2004.

Vehkalahti, M., Nordblad, A., Suominen-Taipale, L., Arinen, S., Hallikainen, D., Hausen, J., Knuuttila, M., Söderholm, A-L., Varsio, S., Soikkonen, K., Könönen, M. \& Pietilä, P. (2008) Oral Health Examination. In: Heistaro S. (ed.) Methodology Report Health 2000 Survey, pp. 78, 81, 86, 87. Helsinki: Publications of the National Public Health Institute B26/2008.

Willett, W. \& Stampfer, M.J. (1986) Total energy intake: implications for epidemiologic analyses. Am J Epidemiol 124, 17-27.

Woelber, J.P., Bremer, K., Vach, K., König, D., Hellwig, E., Ratka-Krüger, P., Al-Ahmad, A. \& 
Tennert, C. (2016) An oral health optimized diet can reduce gingival and periodontal inflammation in humans - a randomized controlled pilot study. BMC Oral Health 17, 28. 
Table 1. Background characteristics of the two age groups as a whole and stratified according to the level of oral hygiene and the whole study population

\begin{tabular}{|c|c|c|c|c|c|c|c|}
\hline & \multicolumn{3}{|c|}{ 30-49 years } & \multicolumn{3}{|c|}{ 50-79 years } & \multirow{2}{*}{$\begin{array}{c}\text { Total } \\
\mathbf{n}=971\end{array}$} \\
\hline & $\begin{array}{c}\text { All, } \\
n=704\end{array}$ & $\begin{array}{c}\text { Good oral } \\
\text { hygiene } \\
\text { n=217 } \\
\end{array}$ & $\begin{array}{c}\text { Poor oral } \\
\text { hygiene } \\
\text { n= 486 }\end{array}$ & $\begin{array}{c}\text { All, } \\
\mathrm{n}=\mathbf{2 6 7}\end{array}$ & $\begin{array}{c}\text { Good oral } \\
\text { hygiene } \\
n=62\end{array}$ & $\begin{array}{c}\text { Poor oral } \\
\text { hygiene } \\
\text { n=200 }\end{array}$ & \\
\hline & \multicolumn{7}{|c|}{$\mathrm{n}(\%)$} \\
\hline $\begin{array}{l}\text { Sex } \\
\text { Male } \\
\text { Female }\end{array}$ & $\begin{array}{l}364(52) \\
340(48)\end{array}$ & $\begin{array}{c}76(35) \\
141(65)\end{array}$ & $\begin{array}{l}287(59) \\
199(41)\end{array}$ & $\begin{array}{l}151(57) \\
116(43)\end{array}$ & $\begin{array}{l}24(39) \\
38(61)\end{array}$ & $\begin{array}{c}125(63) \\
75(38)\end{array}$ & $\begin{array}{l}515(53) \\
456(47)\end{array}$ \\
\hline $\begin{array}{l}\text { Education } \\
\text { Basic } \\
\text { Intermediate } \\
\text { Higher } \\
\end{array}$ & $\begin{array}{l}187(27) \\
334(48) \\
182(26)\end{array}$ & $\begin{array}{c}54(25) \\
105(48) \\
58(27)\end{array}$ & $\begin{array}{l}133(27) \\
228(47) \\
124(26)\end{array}$ & $\begin{array}{c}144(54) \\
68(26) \\
54(20)\end{array}$ & $\begin{array}{c}37(60) \\
16(26) \\
9(15)\end{array}$ & $\begin{array}{l}102(51) \\
52(26) \\
45(23)\end{array}$ & $\begin{array}{l}331(34) \\
402(41) \\
236(24)\end{array}$ \\
\hline $\begin{array}{l}\text { Level of oral hygiene } \\
\text { No plaque on the indicator } \\
\text { teeth } \\
\text { Plaque on the gingival margin } \\
\text { Plaque elsewhere on the teeth }\end{array}$ & $\begin{array}{l}217(31) \\
362(51) \\
124(18)\end{array}$ & $\begin{array}{c}217(100) \\
0(0) \\
0(0)\end{array}$ & $\begin{array}{c}0(0) \\
362(75) \\
124(26)\end{array}$ & $\begin{array}{c}62(24) \\
145(55) \\
55(21)\end{array}$ & $\begin{array}{c}62(100) \\
0(0) \\
0(0)\end{array}$ & $\begin{array}{c}0(0) \\
145(73) \\
55(28)\end{array}$ & $\begin{array}{l}279(29) \\
\\
507(53) \\
179(19)\end{array}$ \\
\hline 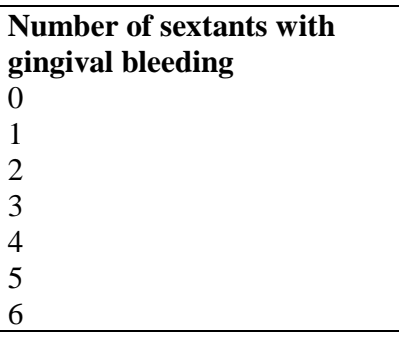 & $\begin{array}{c}181(26) \\
117(17) \\
89(13) \\
96(14) \\
52(7) \\
49(7) \\
120(17) \\
\end{array}$ & $\begin{array}{l}91(42) \\
40(18) \\
33(15) \\
22(10) \\
6(3) \\
13(6) \\
12(6) \\
\end{array}$ & $\begin{array}{c}90(19) \\
76(16) \\
56(12) \\
74(15) \\
46(9) \\
36(7) \\
108(22) \\
\end{array}$ & $\begin{array}{l}67(25) \\
55(21) \\
34(13) \\
28(10) \\
26(10) \\
24(9) \\
33(12) \\
\end{array}$ & $\begin{array}{l}27(44) \\
17(27) \\
4(6) \\
3(5) \\
4(6) \\
4(6) \\
3(5) \\
\end{array}$ & $\begin{array}{l}38(19) \\
35(18) \\
30(15) \\
25(13) \\
22(11) \\
20(10) \\
30(15) \\
\end{array}$ & $\begin{array}{l}248(26) \\
172(18) \\
123(13) \\
124(13) \\
78(8) \\
73(8) \\
153(16) \\
\end{array}$ \\
\hline $\begin{array}{l}\text { Number of teeth with } \geq \mathbf{4} \\
\text { mm deep periodontal } \\
\text { pockets } \\
0 \\
1-3 \\
4-6 \\
7-11 \\
12+\end{array}$ & $\begin{array}{l}227(32) \\
147(21) \\
110(16) \\
86(12) \\
134(19) \\
\end{array}$ & $\begin{array}{l}101(47) \\
53(24) \\
29(13) \\
16(7) \\
18(8) \\
\end{array}$ & $\begin{array}{l}126(26) \\
94(19) \\
80(16) \\
70(14) \\
116(24) \\
\end{array}$ & $\begin{array}{l}50(19) \\
56(21) \\
39(15) \\
52(19) \\
70(26)\end{array}$ & $\begin{array}{l}23(37) \\
16(26) \\
11(18) \\
4(6) \\
8(13) \\
\end{array}$ & $\begin{array}{l}26(13) \\
37(19) \\
27(14) \\
48(24) \\
62(31) \\
\end{array}$ & $\begin{array}{l}277(29) \\
203(21) \\
149(15) \\
138(14) \\
204(21) \\
\end{array}$ \\
\hline $\begin{array}{l}\text { Use of non-steroidal anti- } \\
\text { inflammatory drugs } \\
\text { Yes } \\
\text { No } \\
\text { NA }\end{array}$ & $\begin{array}{c}288(41) \\
336(48) \\
80(11)\end{array}$ & $\begin{array}{c}86(40) \\
109(50) \\
22(10)\end{array}$ & $\begin{array}{c}202(42) \\
227(47) \\
57(12)\end{array}$ & $\begin{array}{c}86(32) \\
151(57) \\
30(11)\end{array}$ & $\begin{array}{c}22(35) \\
36(58) \\
4(7) \\
\end{array}$ & $\begin{array}{c}62(31) \\
112(56) \\
26(13)\end{array}$ & $\begin{array}{l}374(39) \\
487(50) \\
110(11)\end{array}$ \\
\hline
\end{tabular}




\begin{tabular}{|c|c|c|c|c|c|c|c|}
\hline $\begin{array}{l}\text { Physical exercise at least } 30 \\
\text { minutes during leisure or } \\
\text { on the way to work } \\
4-7 \text { times a week } \\
2-3 \text { times a week } \\
\text { once a week } \\
2-3 \text { times a month or less }\end{array}$ & $\begin{array}{l}123(18) \\
182(26) \\
164(23) \\
232(33) \\
\end{array}$ & $\begin{array}{l}40(19) \\
56(26) \\
57(27) \\
62(29) \\
\end{array}$ & $\begin{array}{l}83(17) \\
125(26) \\
107(22) \\
170(35) \\
\end{array}$ & $\begin{array}{l}49(18) \\
87(33) \\
47(18) \\
82(31) \\
\end{array}$ & $\begin{array}{l}14(23) \\
19(31) \\
10(2) \\
18(30) \\
\end{array}$ & $\begin{array}{l}34(17) \\
66(33) \\
37(19) \\
62(31) \\
\end{array}$ & $\begin{array}{l}172(18) \\
269(28) \\
211(22) \\
314(33) \\
\end{array}$ \\
\hline $\begin{array}{l}\text { Number of cigarettes } \\
\text { smoked per day } \\
1-10 \\
11-20 \\
21-30 \\
31-40 \\
41-50 \\
51-60 \\
\end{array}$ & $\begin{array}{c}270(38) \\
354(50) \\
59(8) \\
17(2) \\
1(0.1) \\
3(0.4) \\
\end{array}$ & $\begin{array}{c}102(47) \\
100(46) \\
13(6) \\
2(1) \\
0(0) \\
0(0)\end{array}$ & $\begin{array}{l}168(35) \\
253(52) \\
46(9) \\
15(3) \\
1(0.2) \\
3(0.6) \\
\end{array}$ & $\begin{array}{c}99(37) \\
134(50) \\
25(9) \\
9(3) \\
0(0) \\
0(0)\end{array}$ & $\begin{array}{c}28(45) \\
29(47) \\
5(8) \\
0(0) \\
0(0) \\
0(0) \\
\end{array}$ & $\begin{array}{l}69(35) \\
103(52) \\
19(10) \\
9(5) \\
0(0) \\
0(0)\end{array}$ & $\begin{array}{c}369(38) \\
488(50) \\
84(9) \\
26(3) \\
1(0.1) \\
3(0.3) \\
\end{array}$ \\
\hline $\begin{array}{l}\text { Dental attendance pattern } \\
\text { Visiting dentist regularly for } \\
\text { a check-up } \\
\text { Visiting dentist only when } \\
\text { experiencing toothache or } \\
\text { other symptoms or never }\end{array}$ & $\begin{array}{l}337(49) \\
345(51)\end{array}$ & $\begin{array}{l}128(62) \\
79(38)\end{array}$ & $\begin{array}{l}209(44) \\
265(56)\end{array}$ & $\begin{array}{l}116(45) \\
142(55)\end{array}$ & $\begin{array}{l}35(57) \\
26(43)\end{array}$ & $\begin{array}{l}81(42) \\
111(58)\end{array}$ & $\begin{array}{l}453(48) \\
487(52)\end{array}$ \\
\hline $\begin{array}{l}\text { Toothbrushing frequency } \\
\text { Twice a day or more } \\
\text { Once a day } \\
\text { Less than once a day or never }\end{array}$ & $\begin{array}{c}408(60) \\
213(31) \\
61(9)\end{array}$ & $\begin{array}{c}139(66) \\
61(29) \\
7(3)\end{array}$ & $\begin{array}{c}269(57) \\
151(32) \\
54(11)\end{array}$ & $\begin{array}{l}135(52) \\
93(36) \\
30(12)\end{array}$ & $\begin{array}{c}37(61) \\
22(36) \\
2(3)\end{array}$ & $\begin{array}{l}94(49) \\
70(36) \\
28(15)\end{array}$ & $\begin{array}{c}543(58) \\
306(33) \\
91(10)\end{array}$ \\
\hline $\begin{array}{l}\text { Use of supplements } \\
\text { Yes } \\
\text { No }\end{array}$ & $\begin{array}{c}95(14) \\
609(87) \\
\end{array}$ & $\begin{array}{c}39(18) \\
178(82) \\
\end{array}$ & $\begin{array}{c}56(12) \\
430(88) \\
\end{array}$ & $\begin{array}{c}42(16) \\
225(84) \\
\end{array}$ & $\begin{array}{l}12(19) \\
50(81) \\
\end{array}$ & $\begin{array}{c}28(14) \\
172(86) \\
\end{array}$ & $\begin{array}{l}137(14) \\
834(86) \\
\end{array}$ \\
\hline & \multicolumn{7}{|c|}{ Mean (SE) } \\
\hline CRP mg/l & $1.8(0.1)$ & $1.5(0.2)$ & $2.0(0.2)$ & $2.8(0.4)$ & $1.8(0.3)$ & $3.2(0.5)$ & $2.1(0.2)$ \\
\hline BMI & $25.7(0.2)$ & $25.8(0.3)$ & $25.7(0.2)$ & $26.6(0.3)$ & $26.3(0.6)$ & $26.6(0.3)$ & $26.0(0.1)$ \\
\hline Alcohol E\% & $2.3(0.1)$ & $2.2(0.2)$ & $2.4(0.2)$ & $2.4(0.2)$ & $1.8(0.3)$ & $2.6(0.3)$ & $2.4(0.1)$ \\
\hline BSDS & $12.9(0.3)$ & $13.4(0.3)$ & $12.6(0.2)$ & $13.0(0.5)$ & $14.5(0.6)$ & $12.5(0.3)$ & $12.9(0.1)$ \\
\hline RFDS & $9.0(0.3)$ & $9.5(0.2)$ & $8.7(0.2)$ & $9.0(0.4)$ & $9.9(0.5)$ & $8.7(0.2)$ & $9.0(0.1)$ \\
\hline
\end{tabular}


Table 2. Background characteristics in tertiles of Baltic Sea Diet Score (BSDS) and Recommended Finnish Diet Score (RFDS) in age groups 30-49 and 50-79 years

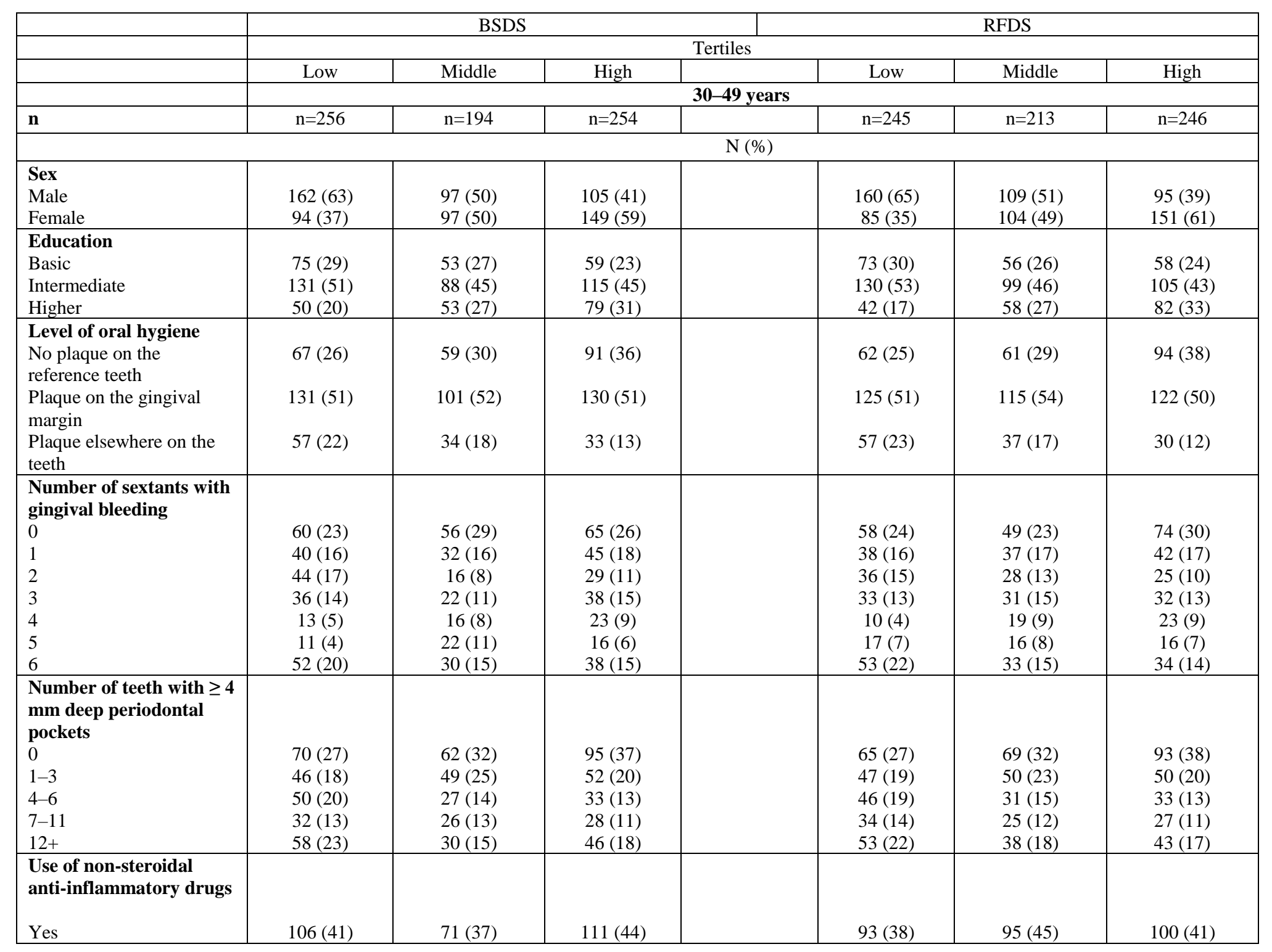




\begin{tabular}{|c|c|c|c|c|c|c|}
\hline $\begin{array}{l}\text { No } \\
\text { NA }\end{array}$ & $\begin{array}{c}114(45) \\
36(14) \\
\end{array}$ & $\begin{array}{l}101(52) \\
22(11) \\
\end{array}$ & $\begin{array}{c}121(48) \\
22(9) \\
\end{array}$ & $\begin{array}{c}114(47) \\
38(16) \\
\end{array}$ & $\begin{array}{c}100(47) \\
18(8) \\
\end{array}$ & $\begin{array}{c}122(50) \\
24(10) \\
\end{array}$ \\
\hline $\begin{array}{l}\text { Physical exercise at least } \\
30 \text { minutes during } \\
\text { leisure or on the way to } \\
\text { work } \\
4-7 \text { times a week } \\
2-3 \text { times a week } \\
\text { once a week } \\
2-3 \text { times a month or less }\end{array}$ & $\begin{array}{c}35(14) \\
62(24) \\
57(22) \\
100(39) \\
\end{array}$ & $\begin{array}{l}30(15) \\
50(26) \\
53(27) \\
61(31) \\
\end{array}$ & $\begin{array}{l}58(23) \\
70(28) \\
54(21) \\
71(28) \\
\end{array}$ & $\begin{array}{l}30(12) \\
60(25) \\
59(24) \\
94(39) \\
\end{array}$ & $\begin{array}{l}38(18) \\
53(25) \\
44(21) \\
78(37) \\
\end{array}$ & $\begin{array}{l}55(22) \\
69(28) \\
61(25) \\
60(24) \\
\end{array}$ \\
\hline $\begin{array}{l}\text { Number of cigarettes } \\
\text { smoked per day } \\
1-10 \\
11-20 \\
21-30 \\
31-40 \\
41-50 \\
51-60 \\
\end{array}$ & $\begin{array}{c}72(28) \\
148(58) \\
29(11) \\
6(2) \\
0(0) \\
1(0.4) \\
\end{array}$ & $\begin{array}{c}78(40) \\
93(48) \\
18(9) \\
4(2) \\
0(0) \\
1(0.5) \\
\end{array}$ & $\begin{array}{c}129(51) \\
113(44) \\
12(5) \\
7(3) \\
1(0.4) \\
1(0.4) \\
\end{array}$ & $\begin{array}{c}69(28) \\
139(57) \\
29(12) \\
6(2) \\
0(0) \\
2(1) \\
\end{array}$ & $\begin{array}{c}80(38) \\
109(51) \\
19(9) \\
5(2) \\
0(0) \\
0(0) \\
\end{array}$ & $\begin{array}{c}121(49) \\
106(43) \\
11(5) \\
6(2) \\
1(0.4) \\
1(0.4) \\
\end{array}$ \\
\hline $\begin{array}{l}\text { Dental attendance } \\
\text { pattern } \\
\text { Visiting dentist regularly } \\
\text { for a check-up } \\
\text { Visiting dentist only when } \\
\text { experiencing toothache or } \\
\text { other symptoms or never }\end{array}$ & $\begin{array}{l}102(41) \\
148(59)\end{array}$ & $\begin{array}{l}95(52) \\
88(48)\end{array}$ & $\begin{array}{l}140(56) \\
109(44)\end{array}$ & $\begin{array}{c}99(42) \\
139(58)\end{array}$ & $\begin{array}{l}105(51) \\
102(49)\end{array}$ & $\begin{array}{l}133(56) \\
104(44)\end{array}$ \\
\hline $\begin{array}{l}\text { Toothbrushing } \\
\text { frequency } \\
\text { Twice a day or more } \\
\text { Once a day } \\
\text { Less than once a day or } \\
\text { never }\end{array}$ & $\begin{array}{l}127(51) \\
97(39) \\
26(10)\end{array}$ & $\begin{array}{c}113(62) \\
54(30) \\
16(9)\end{array}$ & $\begin{array}{c}168(67) \\
62(25) \\
19(8)\end{array}$ & $\begin{array}{l}119(50) \\
90(38) \\
29(12)\end{array}$ & $\begin{array}{c}120(58) \\
66(32) \\
21(10)\end{array}$ & $\begin{array}{c}169(71) \\
57(24) \\
11(5)\end{array}$ \\
\hline $\begin{array}{l}\text { Use of supplements } \\
\text { Yes } \\
\text { No }\end{array}$ & $\begin{array}{c}30(12) \\
226(88)\end{array}$ & $\begin{array}{c}23(12) \\
171(88)\end{array}$ & $\begin{array}{c}42(17) \\
212(83)\end{array}$ & $\begin{array}{c}24(10) \\
221(90)\end{array}$ & $\begin{array}{c}29(14) \\
184(86)\end{array}$ & $\begin{array}{c}42(17) \\
204(83)\end{array}$ \\
\hline \multicolumn{7}{|c|}{ Mean (SE) } \\
\hline CRP mg/l & $1.9(0.3)$ & $2.0(0.3)$ & $1.7(0.2)$ & $2.0(0.3)$ & $1.8(0.2)$ & $1.6(0.2)$ \\
\hline BMI & $25.6(0.3)$ & $25.7(0.3)$ & $26.0(0.2)$ & $25.1(0.3)$ & $25.8(0.3)$ & $26.3(0.2)$ \\
\hline Alcohol E\% & $2.6(0.2)$ & $2.1(0.2)$ & $2.2(0.2)$ & $2.4(0.2)$ & $2.3(0.2)$ & $2.3(0.2)$ \\
\hline & \multicolumn{6}{|c|}{$50-79$ years } \\
\hline $\mathrm{n}$ & $n=93$ & $\mathrm{n}=79$ & $\mathrm{n}=95$ & $\mathrm{n}=92$ & $\mathrm{n}=85$ & $\mathrm{n}=90$ \\
\hline \multicolumn{7}{|c|}{$\mathrm{N}(\%)$} \\
\hline Sex & & & & & & \\
\hline
\end{tabular}




\begin{tabular}{|c|c|c|c|c|c|c|}
\hline $\begin{array}{l}\text { Male } \\
\text { Female }\end{array}$ & $\begin{array}{l}66(71) \\
27(29) \\
\end{array}$ & $\begin{array}{l}43(54) \\
36(46) \\
\end{array}$ & $\begin{array}{l}42(44) \\
53(56) \\
\end{array}$ & $\begin{array}{l}64(70) \\
28(30) \\
\end{array}$ & $\begin{array}{l}\text { (48) } 56 \\
(37) 44 \\
\end{array}$ & $\begin{array}{l}\text { (39) } 43 \\
\text { (51) } 57 \\
\end{array}$ \\
\hline $\begin{array}{l}\text { Level of oral hygiene } \\
\text { No plaque on the indicator }\end{array}$ & $15(17)$ & $12(15)$ & $35(37)$ & $15(16)$ & $17(20)$ & $30(34)$ \\
\hline $\begin{array}{l}\text { Plaque elsewhere on the } \\
\text { teeth }\end{array}$ & $22(24)$ & $15(19)$ & $18(19)$ & $24(26)$ & $17(20)$ & $14(16)$ \\
\hline $\begin{array}{l}\text { Number of sextants with } \\
\text { gingival bleeding } \\
0 \\
1 \\
2 \\
3 \\
4 \\
5 \\
6 \\
\end{array}$ & $\begin{array}{c}21(23) \\
24(26) \\
11(12) \\
10(11) \\
7(8) \\
9(10) \\
11(12) \\
\end{array}$ & $\begin{array}{c}21(27) \\
8(10) \\
11(14) \\
8(10) \\
13(16) \\
9(11) \\
9(11) \\
\end{array}$ & $\begin{array}{l}25(26) \\
23(24) \\
12(13) \\
10(11) \\
6(6) \\
6(6) \\
13(14)\end{array}$ & $\begin{array}{l}17(18) \\
19(21) \\
13(14) \\
9(10) \\
14(15) \\
9(10) \\
11(12)\end{array}$ & $\begin{array}{l}24(28) \\
16(19) \\
8(9) \\
10(12) \\
5(6) \\
11(13) \\
11(13)\end{array}$ & $\begin{array}{l}26(29) \\
20(22) \\
13(14) \\
9(10) \\
7(8) \\
4(4) \\
11(12)\end{array}$ \\
\hline $\begin{array}{l}\text { Number of teeth with } \geq \mathbf{4} \\
\text { mm deep periodontal } \\
\text { pockets } \\
0 \\
1-3 \\
4-6 \\
7-11 \\
12+ \\
\end{array}$ & $\begin{array}{l}14(15) \\
21(23) \\
13(14) \\
14(15) \\
31(33) \\
\end{array}$ & $\begin{array}{l}13(17) \\
13(17) \\
10(13) \\
23(29) \\
20(25) \\
\end{array}$ & $\begin{array}{l}23(24) \\
22(23) \\
16(17) \\
15(16) \\
10(20) \\
\end{array}$ & $\begin{array}{l}11(12) \\
21(23) \\
12(13) \\
18(20) \\
30(33) \\
\end{array}$ & $\begin{array}{l}19(22) \\
15(18) \\
13(15) \\
17(20) \\
21(25) \\
\end{array}$ & $\begin{array}{l}20(22) \\
20(22) \\
14(16) \\
17(19) \\
19(21) \\
\end{array}$ \\
\hline $\begin{array}{l}\text { Use of non-steroidal } \\
\text { anti-inflammatory drugs } \\
\text { Yes } \\
\text { No } \\
\text { NA } \\
\end{array}$ & $\begin{array}{l}32(34) \\
50(54) \\
11(12) \\
\end{array}$ & $\begin{array}{l}24(30) \\
45(57) \\
10(13) \\
\end{array}$ & $\begin{array}{c}30(32) \\
56(59) \\
9(9) \\
\end{array}$ & $\begin{array}{l}31(34) \\
48(52) \\
13(14)\end{array}$ & $\begin{array}{l}25(29) \\
52(61) \\
8(9) \\
\end{array}$ & $\begin{array}{l}30(33) \\
51(57) \\
9(10)\end{array}$ \\
\hline $\begin{array}{l}\text { Number of cigarettes } \\
\text { smoked per day }\end{array}$ & & & & & & \\
\hline
\end{tabular}




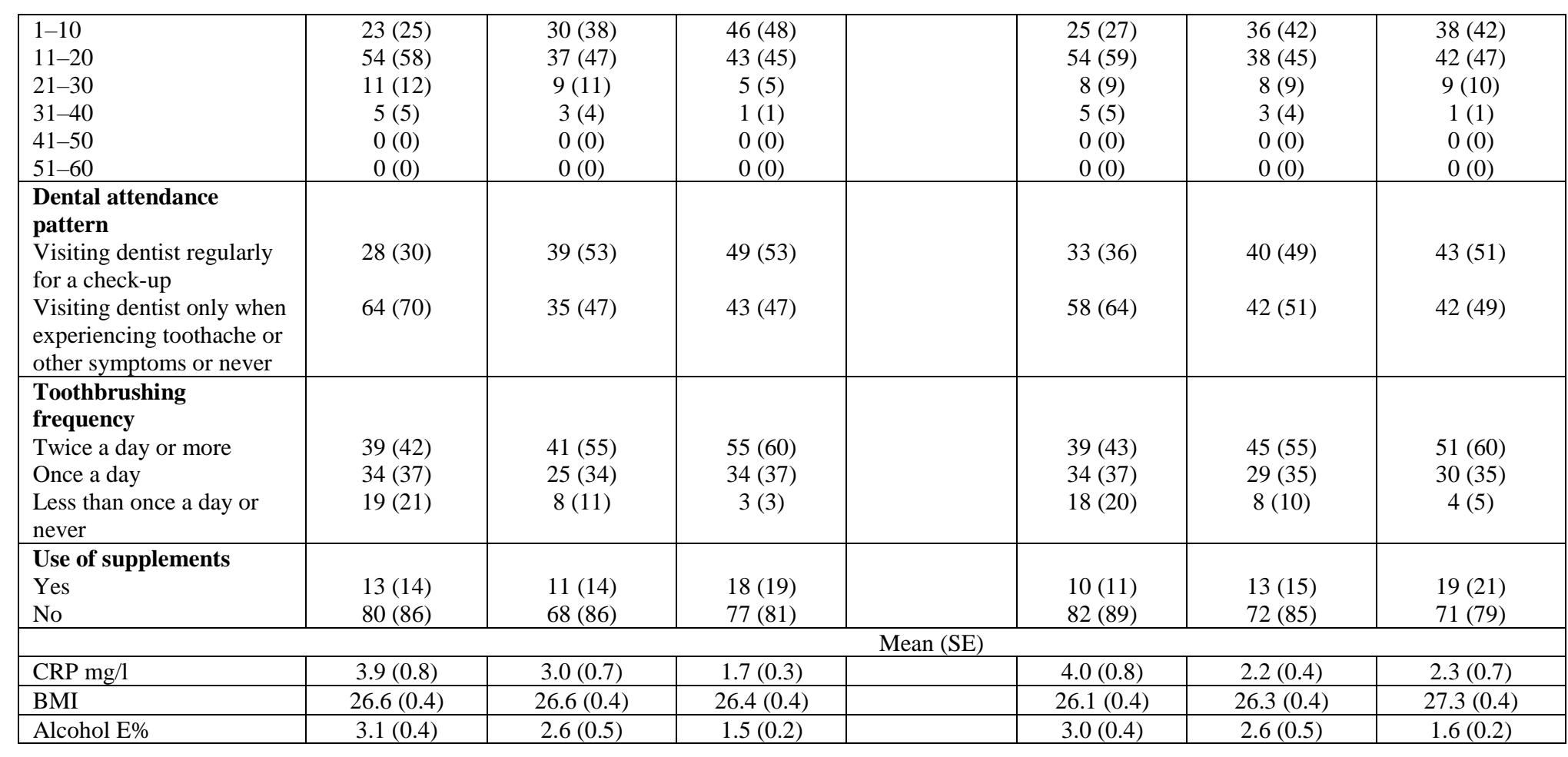


Table 3. Means (SE, standard error) of the Baltic Sea Diet Score (BSDS) and Recommended Finnish Diet Score (RFDS) by age group and the number of sextants with gingival bleeding and the number of teeth with $\geq 4 \mathrm{~mm}$ deep periodontal pockets

\begin{tabular}{|c|c|c|c|c|c|}
\hline $\begin{array}{c}\text { Sextants with gingival } \\
\text { bleeding }\end{array}$ & BSDS & RFDS & $\begin{array}{l}\text { Teeth with } \geq 4 \mathrm{~mm} \text { deep } \\
\text { periodontal pockets }\end{array}$ & BSDS & RFDS \\
\hline \multicolumn{6}{|c|}{$30-49$ years $\quad(n=704)$} \\
\hline & \multicolumn{2}{|c|}{ Mean (SE) } & & \multicolumn{2}{|c|}{ Mean (SE) } \\
\hline $0(\mathrm{n}=362)$ & $13.1(0.3)$ & $9.3(0.3)$ & $0(\mathrm{n}=580)$ & $13.4(0.3)$ & $9.5(0.2)$ \\
\hline $1(\mathrm{n}=183)$ & $13.0(0.4)$ & $9.1(0.3)$ & $1-3(n=342)$ & $13.0(0.4)$ & $9.1(0.3)$ \\
\hline $2(\mathrm{n}=163)$ & $12.1(0.5)$ & $8.5(0.4)$ & $4-6(n=129)$ & $12.2(0.4)$ & $8.6(0.4)$ \\
\hline $3(\mathrm{n}=150)$ & $12.8(0.5)$ & $8.8(0.4)$ & $7-11(\mathrm{n}=113)$ & $12.6(0.4)$ & $8.4(0.4)$ \\
\hline $4(n=113)$ & $13.4(0.6)$ & $9.6(0.4)$ & $12+\quad(n=46)$ & $12.3(0.4)$ & $8.5(0.3)$ \\
\hline $5(\mathrm{n}=90)$ & $13.0(0.5)$ & $8.5(0.5)$ & & & \\
\hline $6(\mathrm{n}=148)$ & $12.5(0.4)$ & $8.6(0.3)$ & & & \\
\hline \multicolumn{6}{|c|}{$50-79$ years $\quad(n=267)$} \\
\hline $0(n=233)$ & $13.5(0.5)$ & $9.5(0.4)$ & $0(\mathrm{n}=333)$ & $13.9(0.6)$ & $9.7(0.5)$ \\
\hline $1(\mathrm{n}=180)$ & $13.0(0.6)$ & $9.2(0.5)$ & $1-3(n=271)$ & $13.4(0.6)$ & $8.9(0.5)$ \\
\hline $2(\mathrm{n}=129)$ & $13.3(0.8)$ & $9.4(0.6)$ & $4-6(n=165)$ & 13.2. (0.7) & $9.7(0.5)$ \\
\hline $3(n=142)$ & $12.6(0.8)$ & $8.6(0.7)$ & $7-11(n=131)$ & $12.7(0.5)$ & $8.9(0.4)$ \\
\hline
\end{tabular}




\begin{tabular}{|c|c|c|c|c|c|}
\hline $4(\mathrm{n}=96)$ & $12.2(0.6)$ & $8.1(0.7)$ & $12+(\mathrm{n}=77)$ & $12.0(0.4)$ & \\
$5(\mathrm{n}=80)$ & $11.7(0.7)$ & $7.8(0.6)$ & & & \\
$6(\mathrm{n}=116)$ & $13.0(0.7)$ & $9.3(0.5)$ & & & \\
& & & & & \\
\end{tabular}


Table 4. Associations of the Baltic Sea Diet Score (BSDS) and the Recommended Finnish Diet Score (RFDS) with the number of sextants with gingival bleeding first in unadjusted and adjusted models and then stratified according to the level of oral hygiene. Prevalence rate ratios and 95\% confidence intervals obtained from Poisson regression models

\begin{tabular}{|c|c|c|c|c|}
\hline & & \multicolumn{3}{|c|}{ Adjusted } \\
\hline & Unadjusted & Model $^{1}$ & Good oral hygiene $^{2,3}$ & Poor oral hygiene $^{3,4}$ \\
\hline $30-49$ years & $\mathrm{n}=704$ & $\mathrm{n}=670$ & $\mathrm{n}=205$ & $\mathrm{n}=465$ \\
\hline BSDS, continuous & $\begin{array}{c}0.99(0.98-1.01) \\
\mathrm{p}=0.246\end{array}$ & $\begin{array}{l}1.01(1.00-1.03) \\
\quad p=0.166\end{array}$ & $\begin{array}{l}1.00(0.96-1.05) \\
\mathrm{p}=0.833\end{array}$ & $\begin{array}{c}1.01(0.99-1.03) \\
\mathrm{p}=0.307\end{array}$ \\
\hline \multicolumn{5}{|c|}{$\begin{array}{l}\text { BSDS tertiles: range (number of } \\
\text { subjects) }\end{array}$} \\
\hline Low: 2-11 (n=256) & . & . & - & - \\
\hline Middle: $12-14(n=194)$ & $0.96(0.82-1.13)$ & $1.03(0.88-1.20)$ & $1.10(0.74-1.64)$ & $1.02(0.84-1.23)$ \\
\hline High: 15-24 (n=254) & $\begin{array}{c}0.94(0.80-1.10) \\
\mathrm{p}=0.719\end{array}$ & $\begin{array}{c}1.09(0.94-1.26) \\
\mathrm{p}=0.515\end{array}$ & $\begin{array}{c}1.06(0.71-1.57) \\
p=0.899\end{array}$ & $\begin{array}{c}1.07(0.91-1.27) \\
\mathrm{p}=0.682\end{array}$ \\
\hline RFDS, continuous & $\begin{array}{c}0.98(0.96-1.00) \\
\mathrm{p}=0.022\end{array}$ & $\begin{array}{c}1.00(0.98-1.02) \\
\mathrm{p}=0.936\end{array}$ & $\begin{array}{c}0.98(0.93-1.03) \\
\quad \mathrm{p}=0.474\end{array}$ & $\begin{array}{c}1.00(0.98-1.02) \\
\mathrm{p}=0.950\end{array}$ \\
\hline \multicolumn{5}{|c|}{$\begin{array}{l}\text { RFDS tertiles: range (number of } \\
\text { subjects) }\end{array}$} \\
\hline Low: 0-7 (n=245) & - & - & - & - \\
\hline Middle: 8-10 (n=213) & $0.92(0.80-1.07)$ & $1.01(0.87-1.16)$ & $0.82(0.52-1.30)$ & $1.03(0.88-1.20)$ \\
\hline High: $11-18(n=246)$ & $\begin{array}{c}0.82(0.70-0.96) \\
p=0.053\end{array}$ & $\begin{array}{c}0.97(0.82-1.15) \\
\mathrm{p}=0.902\end{array}$ & $\begin{array}{c}0.84(0.58-1.21) \\
\mathrm{p}=0.579\end{array}$ & $\begin{array}{c}0.97(0.80-1.17) \\
\mathrm{p}=0.807\end{array}$ \\
\hline $50-79$ years & $n=267$ & $n=250$ & $\mathrm{n}=60$ & $\mathrm{n}=190$ \\
\hline BSDS, continuous & $\begin{array}{l}0.98(0.96-1.00) \\
\quad \mathrm{p}=0.070\end{array}$ & $\begin{array}{c}0.99(0.96-1.02) \\
\mathrm{p}=0.387\end{array}$ & $\begin{array}{c}1.02(0.95-1.10) \\
\mathrm{p}=0.618\end{array}$ & $\begin{array}{l}0.98(0.96-1.01) \\
\mathrm{p}=0.120\end{array}$ \\
\hline \multicolumn{5}{|c|}{$\begin{array}{l}\text { BSDS tertiles: range (number of } \\
\text { subjects) }\end{array}$} \\
\hline Low: 2-11 (n=93) & - & - & - & - \\
\hline Middle: $12-14(\mathrm{n}=79)$ & $1.00(0.79-1.26)$ & $1.06(0.85-1.33)$ & $1.26(0.21-7.56)$ & $1.10(0.89-1.36)$ \\
\hline High: 15-24 (n=95) & $\begin{array}{l}0.89(0.70-1.13) \\
\mathrm{p}=0.562\end{array}$ & $\begin{array}{l}0.98(0.76-1.26) \\
\quad p=0.747\end{array}$ & $\begin{array}{c}1.43(0.57-3.57) \\
\mathrm{p}=0.614\end{array}$ & $\begin{array}{l}0.94(0.74-1.20) \\
\quad \mathrm{p}=0.414\end{array}$ \\
\hline RFDS, continuous & $\begin{array}{c}0.97(0.94-1.00) \\
\mathrm{p}=0.024\end{array}$ & $\begin{array}{c}0.99(0.96-1.02) \\
\mathrm{p}=0.348\end{array}$ & $\begin{array}{c}0.99(0.90-1.09) \\
\mathrm{p}=0.868\end{array}$ & $\begin{array}{l}0.98(0.95-1.01) \\
\mathrm{p}=0.237\end{array}$ \\
\hline \multicolumn{5}{|c|}{$\begin{array}{l}\text { RFDS tertiles: range (number of } \\
\text { subjects) }\end{array}$} \\
\hline Low: 1-7 (n=92) & - & - & - & - \\
\hline Middle: $8-10(\mathrm{n}=85)$ & $0.89(0.70-1.13)$ & $0.90(0.73-1.11)$ & $0.54(0.20-1.49)$ & $0.98(0.79-1.22)$ \\
\hline High: $11-17(\mathrm{n}=90)$ & $0.77(0.60-0.99)$ & $0.90(0.69-1.16)$ & $0.77(0.34-1.76)$ & $0.86(0.67-1.11)$ \\
\hline
\end{tabular}


The number of measured sextants was used as an offset variable

${ }^{1}$ Adjusted for age, gender, level of education, dental attendance pattern, toothbrushing frequency, oral hygiene, body mass index, number of cigarettes smoked, logarithmically transformed Creactive protein, the use of supplements, NSAID use and physical exercise.

${ }^{2}$ No plaque on the reference teeth.

${ }^{3}$ Adjusted for age, gender, level of education, dental attendance pattern, toothbrushing frequency, body mass index, number of cigarettes smoked, logarithmically transformed C-reactive protein, the use of supplements, NSAID use and physical exercise.

${ }^{4}$ Plaque on the gingival margin or elsewhere on the reference teeth. 
Table 5. Associations of the Baltic Sea Diet Score (BSDS) and the Recommended Finnish Diet Score (RFDS) with the number of teeth with deepened periodontal pockets first in unadjusted and adjusted models and then stratified according to the level of oral hygiene. Prevalence rate ratios and $95 \%$ confidence intervals obtained from Poisson regression models

\begin{tabular}{|c|c|c|c|c|}
\hline & & & Adjusted & \\
\hline & Unadjusted & Model $^{1}$ & Good oral hygiene $^{2,3}$ & Poor oral hygiene 3,4 \\
\hline $30-49$ years & $\mathrm{n}=704$ & $\mathrm{n}=670$ & $\mathrm{n}=205$ & $\mathrm{n}=465$ \\
\hline BSDS, continuous & $\begin{array}{c}0.98(0.95-1.00) \\
\mathrm{p}=0.068\end{array}$ & $\begin{array}{c}1.00(0.98-1.02) \\
\mathrm{p}=0.862\end{array}$ & $\begin{array}{l}0.98(0.93-1.04) \\
\quad p=0.489\end{array}$ & $\begin{array}{c}1.00(0.97-1.02) \\
\quad p=0.746\end{array}$ \\
\hline \multicolumn{5}{|l|}{$\begin{array}{l}\text { BSDS tertiles: range (number of } \\
\text { subjects) }\end{array}$} \\
\hline Low: 2-11 (n=256) & - & - & - & - \\
\hline Middle: $12-14(\mathrm{n}=194)$ & $0.80(0.63-1.02)$ & $0.89(0.71-1.11)$ & $0.58(0.35-0.93)$ & $0.95(0.73-1.22)$ \\
\hline High: $15-24(n=254)$ & $\begin{array}{l}0.84(0.66-1.07) \\
\quad \mathrm{p}=0.162\end{array}$ & $\begin{array}{c}0.97(0.77-1.21) \\
\mathrm{p}=0.564\end{array}$ & $\begin{array}{l}0.78(0.51-1.20) \\
\mathrm{p}=0.078\end{array}$ & $\begin{array}{l}0.98(0.76-1.25) \\
\quad p=0.912\end{array}$ \\
\hline RFDS, continuous & $\begin{array}{l}0.97(0.95-0.99) \\
\mathrm{p}=0.012\end{array}$ & $\begin{array}{c}0.99(0.96-1.01) \\
\mathrm{p}=0.335\end{array}$ & $\begin{array}{l}0.95(0.90-1.00) \\
\quad \mathrm{p}=0.042\end{array}$ & $\begin{array}{l}0.99(0.96-1.01) \\
\quad \mathrm{p}=0.313\end{array}$ \\
\hline \multicolumn{5}{|l|}{$\begin{array}{l}\text { RFDS tertiles: range (number of } \\
\text { subjects) }\end{array}$} \\
\hline Low: 0-7 (n=245) & - & - & - & - \\
\hline Middle : 8-10 (n=213) & $0.84(0.68-1.04)$ & $0.97(0.79-1.19)$ & $0.60(0.37-0.98)$ & $0.99(0.79-1.24)$ \\
\hline High: $11-18(n=246)$ & $\begin{array}{c}0.79(0.64-0.97) \\
\mathrm{p}=0.053\end{array}$ & $\begin{array}{c}0.90(0.74-1.10) \\
p=0.566\end{array}$ & $\begin{array}{c}0.63(0.43-0.92) \\
p=0.027\end{array}$ & $\begin{array}{c}0.91(0.73-1.14) \\
\mathrm{p}=0.681\end{array}$ \\
\hline 50-79 years & $\mathrm{n}=267$ & $\mathrm{n}=250$ & $\mathrm{n}=60$ & $\mathrm{n}=190$ \\
\hline BSDS, continuous & $\begin{array}{c}0.97(0.95-1.00) \\
\mathrm{p}=0.030\end{array}$ & $\begin{array}{c}1.00(0.97-1.03) \\
\mathrm{p}=0.922\end{array}$ & $\begin{array}{l}0.98(0.90-1.06) \\
\quad p=0.617\end{array}$ & $\begin{array}{l}1.00(0.98-1.03) \\
\quad \mathrm{p}=0.835\end{array}$ \\
\hline \multicolumn{5}{|l|}{$\begin{array}{l}\text { BSDS tertiles: range (number of } \\
\text { subjects) }\end{array}$} \\
\hline Low: $2-11(n=93)$ & - & - & - & - \\
\hline Middle: $12-14(\mathrm{n}=79)$ & $0.88(0.69-1.13)$ & $1.08(0.86-1.35)$ & $0.77(0.31-1.88)$ & $1.17(0.94-1.46)$ \\
\hline High: 15-24 (n=95) & $\begin{array}{l}0.77(0.60-0.98) \\
\quad p=0.105\end{array}$ & $\begin{array}{l}0.97(0.74-1.29) \\
\mathrm{p}=0.705\end{array}$ & $\begin{array}{l}0.79(0.38-1.66) \\
\mathrm{p}=0.783\end{array}$ & $\begin{array}{l}1.06(0.83-1.35) \\
\quad \mathrm{p}=0.372\end{array}$ \\
\hline RFDS, continuous & $\begin{array}{l}0.96(0.93-1.00) \\
\quad p=0.037\end{array}$ & $\begin{array}{c}1.00(0.96-1.03) \\
\mathrm{p}=0.844\end{array}$ & $\begin{array}{c}0.97(0.89-1.07) \\
\mathrm{p}=0.548\end{array}$ & $\begin{array}{l}1.00(0.96-1.03) \\
\quad \mathrm{p}=0.840\end{array}$ \\
\hline RFDS tertiles: range (number of & & & & \\
\hline
\end{tabular}




\begin{tabular}{|l|c|c|c|c|}
\hline subjects) & & & & \\
Low: $1-7(\mathrm{n}=92)$ & - & - & - & - \\
Middle: $8-10(\mathrm{n}=85)$ & $0.77(0.59-1.00)$ & $0.87(0.69-1.10)$ & $0.50(0.25-0.98)$ & $0.93(0.73-1.19)$ \\
High: $11-17(\mathrm{n}=90)$ & $0.79(0.61-1.02)$ & $1.03(0.80-1.33)$ & $0.64(0.29-1.39)$ & $1.04(0.79-1.37)$ \\
& $\mathrm{p}=0.076$ & $\mathrm{p}=0.364$ & $\mathrm{p}=0.124$ & $\mathrm{p}=0.749$ \\
\hline
\end{tabular}

The number of teeth was used as an offset variable

${ }^{1}$ Adjusted for age, gender, level of education, dental attendance pattern, toothbrushing frequency, oral hygiene, body mass index, number of cigarettes smoked, logarithmically transformed Creactive protein, the use of supplements, NSAID use and physical exercise.

${ }^{2}$ No plaque on the reference teeth.

${ }^{3}$ Adjusted for age, gender, level of education, dental attendance pattern, toothbrushing frequency, body mass index, number of cigarettes smoked, logarithmically transformed C-reactive protein, the use of supplements, NSAID use and physical exercise.

${ }^{4}$ Plaque on the gingival margin or elsewhere on the reference teeth. 